\title{
Rehabilitating benefits and its sustainability of a degraded semi-arid Rangeland in Yabello Southern Ethiopia
}

\begin{abstract}
Rehabilitating the degraded rangeland in Ethiopia is very crucial issue for improving the livelihood of pastoralist life style and the environmental sustainability of the country. In Yabello rangeland area the local communities used enclosure method in order to rehabilitate the degraded rangeland area and try to address their livelihood problems. In general the current study tried to assess the benefits obtained from the rehabilitated rangeland area from the three study site chosen through purposively techniques based on the information gathered from different aspect. Semi- structured interview, Focal group discussion was held with key informants and different stakeholders at each kebele level have been conducted to gather information from the total of 150 respondents (50 from each kebele) and analyzed both in qualitative and quantitative approaches. The result showed that the rehabilitated rangeland area mainly used to get both numerical and non-numerical benefits like livestock fattening, grazing purpose, wood cutting and charcoal production and among this livestock fatting is the major source of income across the whole study site and Dida Tuyura (A1) is the most productive site among the rest. From this we recommend that there is a need to enhance market linkages for restored rangeland products that would then drive the adoption of rangeland restoration initiatives and those helps for sustainable utilization of the rehabilitated.
\end{abstract}

Keywords: rehabilitation, yabello, degraded rangeland, benefits, sustainability
Volume 4 Issue 4 - 2019

\section{Yeneayehu Fenetahun,' Xu-Xinwen, ${ }^{2}$ Wang Yong-dong ${ }^{2}$}

'Department of Ecology Xinjiang Institution of Ecology and Geography, University of china Academy of Science (UCAS), China

2Department of Dry land Ecology, Xinjiang Institution of Ecology and Geography, Chinese Academy of Science (CAS), China

Correspondence: Wang Yong-dong, Department of Dry land Ecology, Xinjiang Institution of Ecology and Geography, Chinese Academy of Science (CAS), Urumqi8300 I I, Xinjiang, China, Tel +86139991505554, Email wangyd@ms.xjb.ac.cn

Received: July 05, 2019 | Published: July 24, 2019

\section{Introduction}

Rangeland degradation in the semi-air rangeland of Yabello is a well-known and challenging problem for pastoralists. ${ }^{1}$ Both climatic and anthropogenic factors are the major rangeland degradation process simultaneously takes away the capacity of the land to provide regulating, socio-cultural and supporting services. ${ }^{2}$ A few decades ago, the Yabello rangelands in southern Ethiopia were considered amongst the best grazing lands in east Afric. ${ }^{3}$ Because of the global climate change and the intensive human activities, desertification/ land degradation has become the most serious problem in the modern society, particularly in the ecologically sensitive arid and semi-arid areas. Rangeland degradation implies a reduction in rank or status, which includes a loss of top-soil, a change to a simple floral/fauna composition or a transition from one organic form to a lower organic form, and continuous reduction of productivity/biomass of the ecosystem. ${ }^{4}$ Once rangeland has been degraded, it is often possible to rehabilitate it and thus restore it to a level of utility, possibly not as its original state, but better than it was in its damaged state. ${ }^{5}$ Rangeland degradation is the most extensive types of current land use problems mainly in Yabello area. Overgrazing by livestock is the principal land problem in the arid and semi-arid regions, coupled with land use change to cultivated farmland in the many countries including Ethiopia. ${ }^{4}$ Changes in natural vegetation dominated by the grass layer, leading to dominance of woody cover and increase in unpalatable forbs are considered as a threat to range conditions in Yabello. ${ }^{6}$ Restoration of land degradation is essential to ensure long term productivity of semi-arid rangeland of Yabello. For improving pasture quantity and quality where graminoid and nongraminoid herbaceous plant species have disappeared have been limited to destocking, bush management, and intermittent grazing ${ }^{7}$ and its basic objective is to encourage palatable, productive perennials, as they are good for animal performance and to maintain a healthy environment. ${ }^{8}$ Other methods such as ripping and grass reseeding has the potential to restore degraded rangelands and improve their potential for livestock production. ${ }^{9}$ The Yabello pastoralists traditionally practiced strategic grazing management to avoid local overstocking around the scarce dry season water sources. The different measures taken were: cultivation of land, share cropping, formal employment in mechanized farms and other organizations, casual labor and small trade. As documented by Solomon, ${ }^{10}$ most of these strategies were utilized by pastoralists for risk management strategies when sole dependency on livestock is in question. Understanding the socio-economic impacts of rangeland rehabilitation is essential to the management and planning of similar initiatives. So this study aimed to quantify the benefits derived from the rehabilitated semi-arid rangeland in Yabello area, Southern Ethiopia.

\section{Materials and methods}

\section{Description of the study area}

The study was made at Dida Tuyura, Danbal-Waccu and Arero kebele of Yabello district Borana zone, southern Ethiopia in 2018. It is situated at $566 \mathrm{~km}$ south of Addis Ababa along Addis-Moyale road. The area of Yabello town is $5426 \mathrm{~km}^{2}$, and located between $4^{\circ} 30^{\prime} 55.81^{\prime \prime}$ and $5^{\circ} 24^{\prime} 36.39^{\prime \prime}$ north latitude and between $7^{\circ} 44^{\prime} 14.70^{\prime \prime}$ and $38^{\circ} 36^{\prime} 05.35^{\prime \prime}$ east longitudes, the altitude is about $1000-1500 \mathrm{~m}$, maximum altitude of $2000 \mathrm{~m}$. The area has a bi-modal rainfall regime, with mean annual rainfall ranging from $400 \mathrm{~mm}$ in the south to $600 \mathrm{~mm}$ 
in the north. Which is the $73 \%$ of rainfall occur in March to May, the $27 \%$ of rainfall occur in September to November. ${ }^{11}$ The potential evapotranspiration is $700-3000 \mathrm{~mm} .{ }^{12}$ The study area also dominated by savannah vegetation containing mixtures of perennial herbaceous vegetation. It is also confronted with the problem of bush expansion in the native savannah grass lands. Besides the area characterized by savanna grass land. There is no detailed information on the soils of Yabello rangelands. However, the main soils of the region comprise $53 \%$ red sandy loam soil, $30 \%$ black clay and volcanic light coloured silty clay and $17 \%$ silt and vertisols (Coppock 1994). Four major vegetation types have been described:

(i) Evergreen and semi-evergreen bush land and thickets, found north of Yabello, Arero and Negelle stretch

(ii) Rangeland dominated by Acacia and Commiphora trees, covering most of the rangeland area extending in central, south and west directions

(iii) Rangeland dominated by shrubby Acacia, Commiphora and allied genera, confined to water sources and depressions covering some portion of the western parts of the rangeland with barren land between

(iv) Dwarf shrub grassland or shrub grassland, in the eastern parts of the rangeland where the soil is very shallow and sandy. According to Coppock (1994), woody plants contribute from $5-75 \%$ of total plant cover on the Yabello plateau depending on location (Figure 1).

\section{Methods data collection}

Three kebeles (Arero, Dada Tuyura and Danbal-Waccu) has been chosen to carry out this research through purposive selection techniques based on the information gathered from different aspect like similarity of terrain, soil, and land use aimed at minimizing variability in the abiotic determinants of rangeland vegetation composition and functioning and hence productivity. And rangelands that rehabilitate by using enclosure methods was selected for this research purpose in order to assessed both the qualitative and quantitative benefits of the local community from this area. Semi- structured interview, Focal group discussion was held with key informants and different stakeholders at each kebele level have been conducted to gather information. The basic issues addressed in the questionnaires include community knowledge about rangeland use, feeding frequency, duration of forage availability for use, critical period of forage shortage, and its proximity. Data of functional both from enclosure and non-enclosure rangeland area were collected to make comparison. Totally 150 respondents, 50 people from three (3) kebeles have been interviewed for the assessment. The ages of respondents were older than 25 years in order to ascertain the efficiency of their experience with impact of forage resource on the study area (Figure 2).

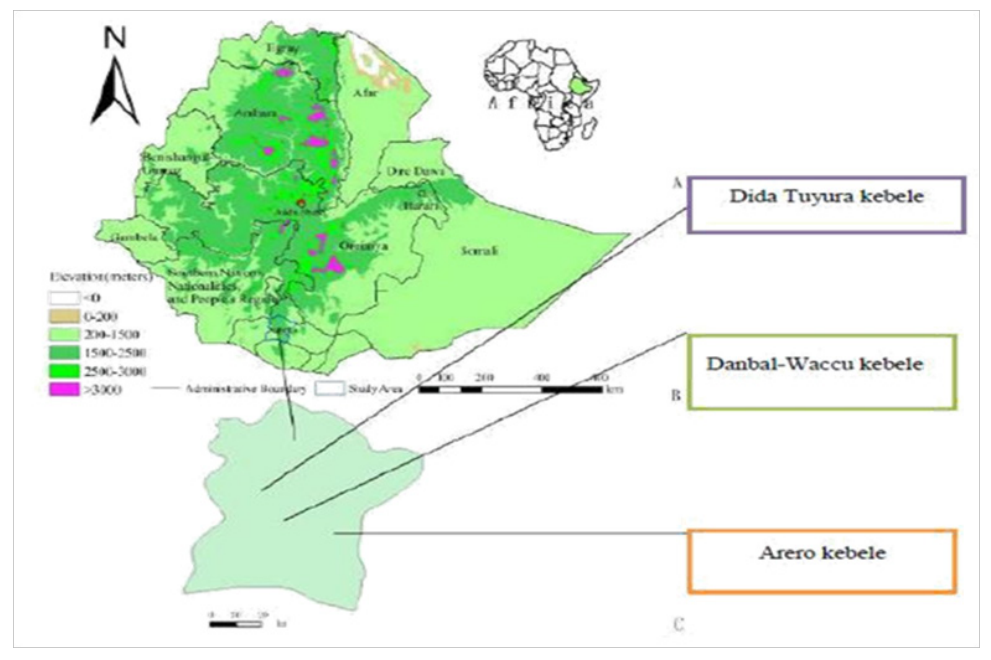

Figure I Geographical location of study areas.

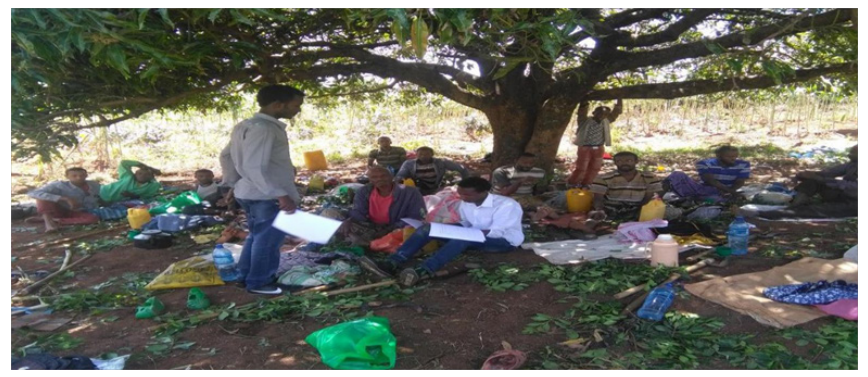

Figure 2 Interview and group discussion with the local community of Yabello pastoralists together with stakeholders (photo taken by Yeneayehu F. Dec/2018). 


\section{Data analysis}

Analysis of data combined both qualitative and quantitative approaches. The analysis began from revising detailed field notes and consolidating similar information from enclosure field reports and sorted out it. The results were categorized into two: the quantitative [tangible product or good that had immediate economic value] and qualitative [those that improved the welfare of the individual household, communities or overall society and the environment but could not be converted immediately into cash]. ${ }^{13}$

\section{Result and discussion}

Based on the data that obtained from the stockholders and interview result the enclosure rangeland area mainly used for livestock fattening, grazing, wood cutting and charcoal burning activates in all of the three sites (Table 1). And the interview result indicated that among the three enclosures rangeland site Dida Tuyura enclosure rangeland generated the highest per hectare income and had the highest number of income generating activities and income portfolio followed by Danbal-Waccu and Arero respectively which is most diversified in terms of income with $83 \%$ coming from Livestock fattening and sale it. And the income rate showed that an increasing trends from time to time (Figures 3-5).

\section{Quantitative benefits}

In the rangelands area that rehabilitated mainly in the enclosures techniques fattening of cattle was the most profitable activity and mainly depends on pasture that obtained from the enclosures

Table I Some general information about the selected enclosed rangelands

\begin{tabular}{lllll}
\hline Code & Local name & Sub-district & Total area (ha) of selected site & Utilization \\
\hline Al & Dida Tuyura & Yabello & 7.5 & LF-G-WC-CB \\
A2 & Danbal-Waccu & Yabello & 7.5 & LF-G-WC-CB \\
A3 & Arero & Yabello & 7.5 & LF-G-WC-CB
\end{tabular}

Note: LF, livestock fattening; G, grazing;WC, wood cutting; CB, charcoal burning

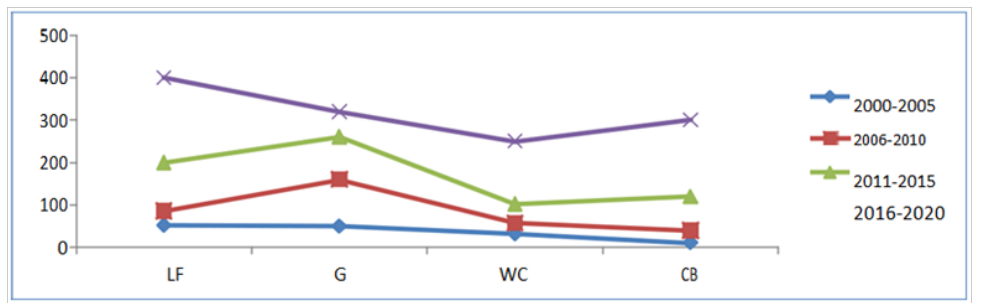

Figure 3 Range land utilization change in number from 2000-2020 in the Dida Tuyura (AI) area (data generated based on the local community interview result) as a result of rehabilitation.

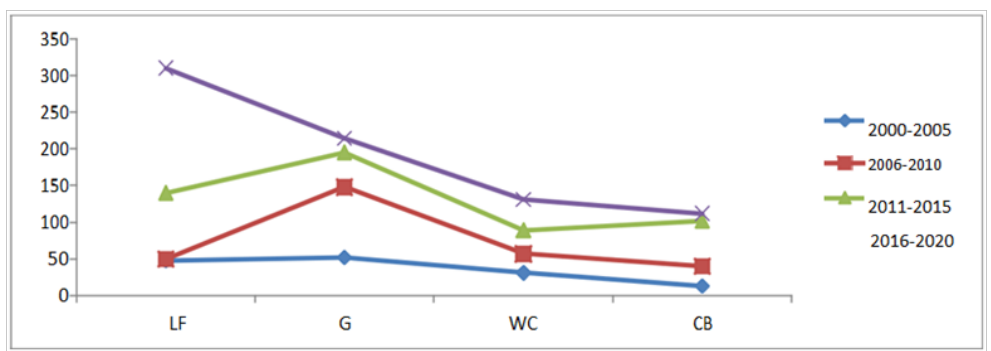

Figure 4 Range land utilization change in number from 2000-2020 in the Danbal-Waccu (A2) area (data generated based on the local community interview result) as a result of rehabilitation. 


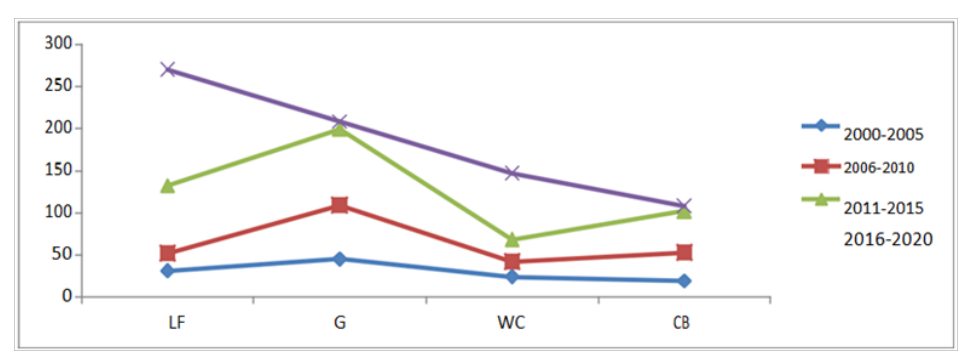

Figure 5 Range land utilization change in number from 2000-2020 in the Arero (A3) area (data generated based on the local community interview result) as a result of rehabilitation.

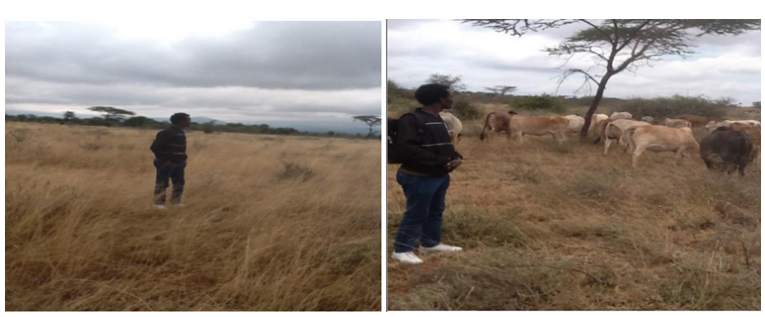

Figure 6 Rehabilitated rangeland area through enclosure (photo taken by Yeneayehu F. Dec/2018 )
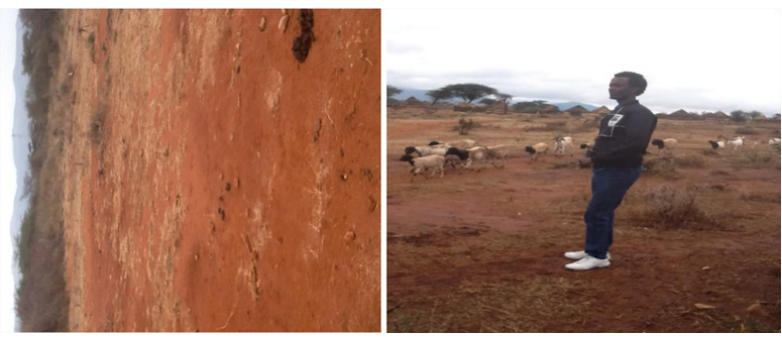

Figure 7 Degraded area (non- enclosure rangeland) with in the same location (photo taken by Yeneayehu F. Dec/20I8).

\section{Qualitative benefits}

In addition to the numerical value, those rehabilitated area have also other non- measurable importance both for the local community and also the livestock and further for environmental issue. Those benefits derived from as a result of rangeland rehabilitation were summarized as follows (Table 2).

Table 2 List of some qualitative benefits derived from rehabilitation of degraded rangeland, measurement methods and ways implemented to be achieved

\begin{tabular}{|c|c|c|}
\hline No. & $\begin{array}{l}\text { Benefits obtained from } \\
\text { rehabilitation of degraded } \\
\text { rangeland }\end{array}$ & Measurement techniques and ways used to achieved the obtained benefit \\
\hline I & $\begin{array}{l}\text { Improved land and livestock } \\
\text { management }\end{array}$ & $\begin{array}{l}\text {-Trained many agropastoralists on rangel and Rehabilitation, grazing management, } \\
\text { sustainable Enclosure utilization practices and diversification of income-generated activities } \\
\text { and opportunities and this efforts are based on realization that there are also other more } \\
\text { alternative benefits with related to both livestock and humans. }\end{array}$ \\
\hline \multirow{2}{*}{2} & \multirow{2}{*}{$\begin{array}{l}\text { Sustainable rangeland } \\
\text { rehabilitation }\end{array}$} & $\begin{array}{l}\text {-Appropriate rehabilitation techniques and water harvesting methods have been defined } \\
\text { and tested. }\end{array}$ \\
\hline & & $\begin{array}{l}\text {-Monitoring exercises carried out in the restored sites show high biodiversity of flora and } \\
\text { fauna compared with the open grazing areas. }\end{array}$ \\
\hline \multirow{5}{*}{3} & \multirow{5}{*}{ Improved communities livelihood } & -Source of good-quality feed for livestock was obtained and observed. \\
\hline & & -Become source income through the sale of grass seeds. \\
\hline & & -Balanced diet obtained from milk especially for children. \\
\hline & & $\begin{array}{l}\text {-Other social amenities like health, education and entertainment facilities were become } \\
\text { observed. }\end{array}$ \\
\hline & & $\begin{array}{l}\text {-Water pans and dams within the established enclosures keep water longer than the ones } \\
\text { in the open rangeland. }\end{array}$ \\
\hline
\end{tabular}

Citation: Fenetahun Y, Xu-Xinwen, Yong-dong W. Rehabilitating benefits and its sustainability of a degraded semi-arid Rangeland in Yabello Southern Ethiopia. MOJ Eco Environ Sci. 2019;4(4):153-158. DOI: 10.15406/mojes.2019.04.00147 
Table Continued

\begin{tabular}{|c|c|c|}
\hline No. & $\begin{array}{l}\text { Benefits obtained from } \\
\text { rehabilitation of degraded } \\
\text { rangeland }\end{array}$ & Measurement techniques and ways used to achieved the obtained benefit \\
\hline \multirow{2}{*}{4} & \multirow{2}{*}{ Crate social cooperation } & $\begin{array}{l}\text {-Individuals or community groups came together to work in the communal enclosures in } \\
\text { the spirit of lemat sera (In Amharic). }\end{array}$ \\
\hline & & $\begin{array}{l}\text {-Increased sustainability of the rangeland rehabilitation initiatives as a result of the } \\
\text { occasional maintenance of the communal enclosures through different activates. }\end{array}$ \\
\hline 5 & $\begin{array}{l}\text { Local community capacity } \\
\text { building }\end{array}$ & $\begin{array}{l}\text {-Trains individuals and community groups as environmental managers, and many have } \\
\text { benefited directly from restored areas and enclosure products. } \\
\text {-The environmental and financial skill capacity building }\end{array}$ \\
\hline
\end{tabular}

Table 3 Some numerical and non-numerical benefits obtained from rehabilitated rangeland area based on the data recorded from the local community during field visit

\begin{tabular}{lllll}
\hline No. & $\begin{array}{l}\text { Benefits obtained from the } \\
\text { rehabilitated area }\end{array}$ & Measuring parameter & $\begin{array}{l}\text { Income source } \\
\text { product }\end{array}$ & $\begin{array}{l}\text { Estimated price } \\
\text { (USD) }\end{array}$ \\
\hline I & Livestock fattening & No. of cattle per day & Fattened & 389 per head \\
2 & Grazing purpose & No. of grazing per day & - & - \\
3 & Wood cutting & No. of tree species cut & Building poles/ & Fencing posts \\
& & & No. of tree cut per bags & Charcoal
\end{tabular}

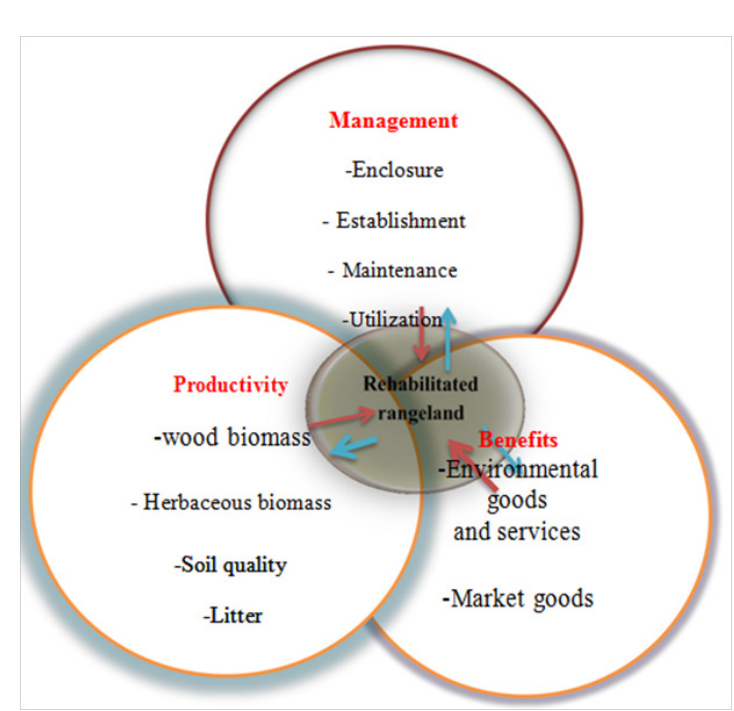

Figure 8 Frame work that shows the linkage between factors and the rehabilitated rangeland area.

\section{Conclusion}

From this study result we can concluded that in all study site (A1A3) the rehabilitated rangeland mainly serve for livestock fattening, grazing purpose, wood cutting and charcoal production and among this livestock fatting is the major source of income across the whole study site and Dida Tuyura (A1) is the most productive site among the rest. In addition to these numerical benefits the rehabilitated area also gives more non-numerical benefits both for livestock and the local community and in the long run for the environmental issue. In general we can recommend that there is a need to enhance market linkages for restored rangeland products that would then drive the adoption of rangeland restoration initiatives and those helps for sustainable utilization of the rehabilitated rangeland and also in order to avoid further degradation of rangeland in the Yabello rangeland area.

\section{Acknowledgments}

We would like to acknowledge University of China academy of science that give us any facilities and finical support to do this research paper as well as our great thanks also goes to the local community of the Yabello district for gave us those basic information and also indicate the factors that are still the challenge for them for our next research step.

\section{Funding}

Science and Technology partnership program, Ministry of Science and Technology of China (KY201702010); China-Africa joint research center project of the Chinese academy of Science (SAJC201610).

\section{Conflicts of interest}

The authors declare that there is no competing of interest.

\section{References}

1. Teshome A, Ayana A. Conversion of savanna rangelands to bush dominated landscape in Borana, Southern Ethiopia. Ecological Processes. 2016;5(6):1-18.

2. Irwin F, Ranganathan J. Restoring nature's capital: an action agenda to sustain ecosystem services. World Resources Institute; 2007:71-80. ISBN 978-1-56973-641-8.

3. Ayana Angassa. The ecological impact of bush encroachment on the yield of grasses in borana rangeland Ecosystem. African J Ecol. 2005;43(1):14 20 .

4. Barrow CJ. Land degradation. Cambridge: Cambridge University Press; 1991.

5. Feyera S, Christine S, Tadese W, et al. Plant diversity, vegetation structure and relationship between Plant communities and environmental variables in The Afromontane forests of Ethiopia. SINET: Ethiop J Sci. 2014;37(2):113-130.

6. Oba G, Post E, Syvertsen PO, et al. Bush cover and range condition assessments in relation to landscape and grazing in southern Ethiopia. Land scape Ecology. 2000;15(6):535-546. 
7. Angassa A. Effects of grazing intensity and bush encroachment on herbaceous species and rangeland condition in southern Ethiopia. Land Degradation \& Development. 2012;25(5):438-451.

8. Saco PM, Willgoose GR, Hancock GR. Eco-geomorphology and vegetation patterns in arid and semi-arid regions. Hydrol Earth Syst Sci Discuss. 2006;3:2559-2593.

9. Mekuria W, Veldkamp E, Tilahun M, et al. Economic valuation of land restoration: The case of exclosures established on communal grazing lands in Tigray, Ethiopia. Land Degradation \& Development. 2001;22(3):334 344.

10. Solomon T, Snyman HA, Smit GN. Rangeland dynamics of southern Ethiopia: (1) Botanical composition of grasses and soil characteristics in relation to land use and distance from water in semi-arid Borana Rangelands. Journal of environmental management. 2007;85(2):429-442.
11. Dalle G, Maass BL, Isselstein J. Rangeland condition and trend in the semi-arid Borana lowlands, southern Oromia, Ethiopia. African Journal of Range \& Forage Science. 2015;23(1):49-58.

12. Billi P, Alemu YT, Ciampalini R. Increased frequency of flash floods in Dire Dawa, Ethiopia: Change in rainfall intensity or human impact? Natural Hazards. 2015;76(2):1373-1394.

13. Stephen M Mureithi, Ann Verdoodt, Jesse T Njoka, et al. Benefits derived from rehabilitating a degraded semi-arid rangeland in communal enclosures, Kenya. Land Degrad. Develop. 2015;27(8):1853-1862.

14. Mekuria W, Veldkamp E, Corre MD, et al. Restoration of ecosystem carbon stocks following exclosure establishment in communal grazing lands in Tigray, Ethiopia. Soil Science Society of America Journal. 2001;75:246-256. 